University of Nebraska - Lincoln

DigitalCommons@University of Nebraska - Lincoln

USDA National Wildlife Research Center - Staff Publications
U.S. Department of Agriculture: Animal and Plant Health Inspection Service

January 2005

Interactions Between the American White Pelican and Aquaculture in the Southeastern United States: an Overview

D. Tommy King

USDA/APHIS/WS National Wildlife Research Center, tommy.king@aphis.usda.gov

Follow this and additional works at: https://digitalcommons.unl.edu/icwdm_usdanwrc

Part of the Environmental Sciences Commons

King, D. Tommy, "Interactions Between the American White Pelican and Aquaculture in the Southeastern United States: an Overview" (2005). USDA National Wildlife Research Center - Staff Publications. 39. https://digitalcommons.unl.edu/icwdm_usdanwrc/39

This Article is brought to you for free and open access by the U.S. Department of Agriculture: Animal and Plant Health Inspection Service at DigitalCommons@University of Nebraska - Lincoln. It has been accepted for inclusion in USDA National Wildlife Research Center - Staff Publications by an authorized administrator of DigitalCommons@University of Nebraska - Lincoln. 


\title{
Interactions Between the American White Pelican and Aquaculture in the Southeastern United States: an Overview
}

\author{
D. TOMMY KING
}

\author{
USDA/WS National Wildlife Research Center; P.O. Box 6099; MS State Univ., MS 39762 \\ Internet: Tommy.King@aphis.usda.gov
}

\begin{abstract}
The eastern metapopulation of the American White Pelican (Pelecanus erythrorhynchos) breeds mainly in the Northern Great Plains, migrates through the Great Plains and along the Mississippi River and winters in the lower Mississippi River Valley and along the Gulf of Mexico. The production of farm-raised Channel Catfish (Ictalurus punctatus) in the southeastern United States has increased dramatically in the last 25 years. In 1990, U.S. Department of Agriculture Wildlife Services offices in Arkansas, Louisiana and Mississippi began receiving complaints concerning the foraging of pelicans in commercial Channel Catfish ponds. Because of the relatively shallow depth and high fish-stocking rates used by most catfish producers, these ponds provide an ideal foraging environment for the American White Pelican. Although the impact of foraging pelicans can be economically significant, the potential for pelicans to transmit trematode infections and other diseases to aquaculture facilities can be more destructive. Damage abatement recommendations have consisted of harassment measures similar to those used for other piscivorous birds, U.S. Fish and Wildlife Service Depredation Permits, and harassing the birds at their loafing sites.

Key words.- - aquaculture, American White Pelican, Bolbophorus, Channel Catfish, Ictalurus punctatus, Pelecanus erythrorhynchos, United States, wildlife damage management.
\end{abstract}

Waterbirds 28 (Special Publication 1): 83-86, 2005

The North American Continental Divide generally separates the American White Pelican (Pelecanus erythrorhynchos) into two relatively distinct metapopulations (Evans and Knopf 1993; Johnsgard 1993; King and Anderson 2005). The eastern metapopulation breeds mainly in the Northern Great Plains and migrates through the Great Plains and along the Mississippi River, and winters in the lower Mississippi River Valley and along the Gulf of Mexico (Houston 1972; Strait and Sloan 1975; King and Grewe 2001; King and Michot 2002).

The numbers of pre-fledged American White Pelicans (AWPE) banded at Marsh Lake, Minnesota and recovered near aquaculture areas in Arkansas, Louisiana and Mississippi increased 18-fold since 1985, concurrent with the rapid expansion of the aquaculture industry, indicating that aquaculture may provide an important food source and attract wintering and migrating pelicans (King and Grewe 2001). Aerial surveys in northwestern Mississippi during the winters of 1993-97 revealed that AWPE numbers reached a peak of about 4,600 in February and March, corresponding with the onset of spring migration (King 1997; King and Werner 2001). Additional aerial surveys in De- cember, February and April 1997-99 in coastal Louisiana and northwestern Mississippi and in January on the Gulf of Mexico coast (King and Michot 2002) found that AWPE numbers in northwestern Mississippi were consistent with those reported by King and Werner (2001). These surveys also revealed that coastal Louisiana consistently held the highest numbers $(18,000-35,000$ or $16-32 \%$ of the eastern metapopulation) and may be the most important wintering area for the AWPE east of the Rocky Mountains (King and Michot 2002; King and Anderson 2005).

The production of farm-raised Channel Catfish (Ictalurus punctatus) in the southeastern United States has increased dramatically in the last 25 years. In 2003, Alabama, Arkansas, Louisiana and Mississippi led the nation in production of farm-raised catfish with approximately 72,000 ha of ponds. In Mississippi alone, 44,112 ha of catfish ponds were in production (U.S. Department of Agriculture 2003). In a 1988 survey, Mississippi catfish producers estimated that they spent $\$ 2.1$ million per year on efforts to control predation by fish-eating birds (Stickley and Andrews 1989). A 1996 survey of catfish producers by the Centers for Epidemiology and Animal Health (CEAH) indicated that the two primary sourc- 
es of catfish losses in commercial operations were disease $(45 \%)$ and wildlife $(37 \%)$ (CEAH 1997a). The primary birds cited by catfish producers as causing most predation problems were the Double-crested Cormorant (Phalacrocorax auritus), herons and egrets, and the AWPE (Wywialowski 1999).

In 1990, U.S. Department of Agriculture Wildlife Services offices in Arkansas, Louisiana and Mississippi began receiving reports of the AWPE foraging in catfish ponds (King 1997). As many as 2,000 individuals have been observed foraging in one 6-ha pond in Mississippi (King 1997; King and Michot 2002). AWPE come into conflict with southeastern aquaculture by exploiting this abundant and readily available food source and by transmitting parasites to uncontaminated fish (King 1997; Overstreet et al. 2002). Pelicans are usually present in the southeastern United States from November through May, but since 1995, several hundred to 2,000 non-breeding individuals have remained in Arkansas, Louisiana and Mississippi throughout the summer (USDA/WS files).

Due to the relatively shallow pond-depth (approximately $1.5 \mathrm{~m}$ ) and high fish stocking densities, catfish ponds provide a near perfect foraging environment for pelicans (King 1997). Understandably, the presence of large numbers of AWPE causes concern among catfish producers. This manuscript provides an overview of American White Pelican interactions with southeastern aquaculture.

\section{Loafing and Foraging Strategies}

In southern Louisiana and northwestern Mississippi, AWPE were monitored to determine their daily activity budgets while using different habitats such as catfish ponds, crawfish ponds, rivers, lakes and bayous (King and Werner 2001). Birds foraging at catfish ponds spent about $4 \%$ of their day foraging and $96 \%$ loafing, whereas birds foraging in other habitats spent about $28 \%$ of their day foraging and $72 \%$ loafing (King and Werner 2001). This difference may be due to AWPE being more efficient in obtaining their food requirements from catfish ponds. For all habitats combined, each individual foraged an average of $2.5 \pm 0.5(\mathrm{SE})$ times $\mathrm{day}^{-1}$ for about $67 \pm 8.1(\mathrm{SE})$ minutes session ${ }^{-1}$ (King and Werner 2001). Birds also foraged in larger flocks for shorter periods of time on catfish ponds than other habitats (King and Werner 2001; King and Michot 2002).

\section{Damage Abatement Recommendations}

Prior to the winter of 1992-93, AWPE predations at catfish facilities in the southeastern United States were limited to short, infrequent visits and the birds were easily dispersed from the area. In recent years however, AWPE have become more persistent in their foraging efforts and therefore, more difficult to disperse from catfish farms (King 1997; Glahn and King 2004). Damage abatement recommendations consist of harassment measures similar to those used for other piscivorous birds (i.e., harassment patrols, pyrotechnics, electronic noise devices, human effigies and propane cannons) (Littauer et al. 1997), issue of U.S. Fish and Wildlife Service predation permits, draining water from flooded fields used as loafing sites and harassment of birds at their loafing sites (King 1997). Because these birds are diurnal and nocturnal foragers (Evans and Knopf 1993; King 1997), 24-h harassment patrols are necessary in areas experiencing problems. Nocturnal foraging individual are easily frightened from catfish ponds by bright spotlights (King 1997).

Prior to 1995, AWPE in Arkansas, Louisiana and Mississippi usually foraged in large flocks. It was common to see $\geq 300$ individuals flying to catfish ponds, foraging and leaving in one flock. In some areas however, individuals have begun to forage in small flocks (1-50 birds), with many flocks spreading out over an entire catfish complex, making harassment and dispersal much more difficult (Glahn and King 2004). This change in foraging strategy may be a result of increased harassment of the birds at catfish ponds. One of the most effective techniques for reducing predation at aquaculture facilities may be to harass the birds at their loafing sites causing the group to abandon the site and often reducing or 
eliminating predation at nearby facilities (King 1997; Glahn and King 2004).

\section{Diet and Predation Problems}

King (1997) found catfish $\leq 34 \mathrm{~cm}$ length in stomachs of AWPE, and several catfish $\geq 53$ $\mathrm{cm}$ length were found in the throats of individuals collected from northwest Mississippi. In the latter cases, individuals apparently tried to swallow catfish that were $\geq 53 \mathrm{~cm}$ in length, tail-first and the pectoral spines of the catfish pierced the bird's throat, preventing swallowing (King 1997). More recently, 28 individuals collected while loafing near catfish ponds in northwestern Mississippi had a diet consisting of $99.6 \%$ catfish by weight (Glahn and King 2004).

Although predation problems associated with AWPE may be economically significant where they occur, these problems are typically more isolated than those caused by cormorants. Only $8 \%$ of catfish producers in Mississippi reported predation problems caused by AWPE in 1996 (Wywialowski 1999). King and Werner (2001) also reported that AWPE were most often observed feeding in lakes but occur in larger flocks on catfish ponds than in other habitats.

In addition to direct consumption of catfish, AWPE have been linked to the transmission of parasitic infections of catfish (Venable et al. 2000; Overstreet et al. 2002; Terhune et al. 2002; Labrie et al. 2004). The AWPE has recently been identified as one of the definitive hosts in the life cycle of commercial catfish parasites, especially the digenetic trematode Bolbophorus damnificus (Overstreet et al. 2002; L. Pote, pers. comm.). This trematode has been reported to cause substantial economic losses to aquaculture producers in Louisiana, Mississippi and Arkansas (Venable et al. 2000; Overstreet et al. 2002; Terhune et al. 2002; Labrie et al. 2004).

\section{Economics of Predation and Control}

Although data are lacking to clearly define the economic impact of AWPE predation, at a regional scale it may be less than that of cormorants because their seasonal abundance is typically lower (Glahn et al. 2000; Glahn and King 2004). However, at a local-scale (the pond), predation can be economically more important than that of cormorants because of the amount and size of catfish consumed. Catfish farmers could potentially lose approximately $\$ 3,000$ from a single day of foraging by a flock of 250 AWPE (Glahn and King 2004). Actual losses would depend on abundance at ponds, the size and number of catfish consumed and the duration of foraging at catfish ponds. For instance, recent fragmentation of some AWPE foraging flocks can lessen the impact on ponds or farms if the number of days the birds forage there can be minimized.

Although the economic impact of AWPE foraging can be great, the potential for birds to transmit trematode infections and other diseases to catfish ponds can be more destructive (Glahn and King 2004). Whole ponds of catfish have died from trematode infections and little can be done to treat these infections (Venable et al. 2000; Overstreet et al. 2002; Terhune et al. 2002; Labrie et al. 2004).

Considering the potential for extensive losses, deterring AWPE from foraging on ponds is warranted. Individuals will immediately begin to forage if allowed to land on catfish ponds. Therefore, farmers should make every effort to prevent flocks from landing on their facilities. Prompt and persistent action is needed to preclude extensive losses. Lack of vigilance by harassment patrols during a mid-day break or at night may allow substantial damage to take place despite control efforts (Glahn and King 2004). Although the costs of control have not been thoroughly assessed, during November 1994 through April 1995, one catfish farmer in southern Louisiana documented his costs for pyrotechnics, ammunition, and labor for AWPE harassment to be $\$ 129,000$ with an additional $\$ 13,000$ spent for extra road and vehicle maintenance (King 1997). Despite these expenditures, this farmer estimated losing $\$ 31,000$ in fish to AWPE predation (King 1997). However, without persistent harassment efforts these losses may have been much higher. 


\section{Research}

Most of the knowledge on AWPE was collected prior to 1980 . The lack of current, thorough ecological data make it difficult for managers to ensure viable numbers while limiting the damage they cause to aquaculture in the southeastern United States. Currently, research is being conducted to determine population dynamics, movements, habitat use, summer ranges and their roles in the distribution of diseases and parasites. Further research should be conducted to determine summer food habits, numbers of breeding birds (see King and Anderson 2005) and to define the economics of predation at aquaculture facilities. The information obtained from these studies will be used to assist managers to develop or refine American White Pelican management strategies.

\section{LiTERATURE CiTED}

CEAH (Centers for Epidemiology and Animal Health). 1997a. Catfish 97: Part I. Reference of 1996 U.S. catfish health and production practices. United States Department of Agriculture, Animal and Plant Health Inspection Service, Veterinary Services, Fort Collins, Colorado.

Evans, R. M. and F. L. Knopf. 1993. American White Pelican. No. 57 in A. Poole and F. Gill (Eds.), The Birds of North America. The Academy of Natural Sciences, Philadelphia, and The American Ornithologists' Union, Washington, DC.

Glahn, J. F. and D. T. King. 2004. Bird Depredation. Chapter 16 in C. S. Tucker and J. A. Hargreaves (Eds.), Biology and Culture of Channel Catfish. Elsevier, New York.

Glahn, J. F., D. S. Reinhold and C. A. Sloan. 2000. Recent population trends of double-crested cormorants wintering in the delta region of Mississippi: responses to roost dispersal and removal under a recent depredation order. Waterbirds 23: 38-44.

Houston, C. S. 1972. Recent Saskatchewan banding of the white pelican. Blue Jay 30: 24-26.

Johnsgard, P. A. 1993. Cormorants, darters, and pelicans of the world. Smithsonian Institution Press, Washington, DC.

King, D. T. 1997. American White Pelicans: The latest avian problem for catfish producers. Pages 31-35 in Proceedings Seventh Eastern Wildlife Damage Management Conference, Jackson, Mississippi, USA. 5-8 November 1995.
King, D. T. and A. H. Grewe, Jr. 2001. Movements and mortality of American white pelicans banded at Marsh Lake, Minnesota. North American Bird Bander 26: 57-60.

King, D. T. and S. J. Werner. 2001. Daily activity budgets and population size of American white pelicans wintering in south Louisiana and the delta region of Mississippi. Waterbirds 24: 250-254.

King, D. T. and T. C. Michot. 2002. Distribution, abundance, and habitat use of American white pelicans in the delta region of Mississippi and along the western Gulf of Mexico coast. Waterbirds 25: 410-416.

King, D. T. and D. W. Anderson. 2005. Recent population status of the American White Pelican: a continental perspective. Waterbirds 28 (Special Publication 1): 48-54.

Labrie, L., C. Komar, J. Terhune, A. Camus and D. Wise. 2004. Effect of sublethal exposure to the trematode Bolbophorus spp. On the severity of Enteric Septicemia of catfish in channel catfish fingerlings. Journal of Aquatic Animal Health 16: 231-237.

Littauer, G. A., J. F. Glahn, D. S. Reinhold and M. W. Brunson. 1997. Control of bird predation at aquaculture facilities: Strategies and cost estimates. Southern Regional Aquaculture Center Publication No. 402 (revised), Mississippi Cooperative Extension Service, Mississippi State, Mississippi.

Overstreet, R. M., S. S. Curran, L. M. Pote, D. T. King, C. K. Blend and W. D. Grater. 2002. Bolbophorus damnificus n. sp. (Digenea Bolbophoridae) from the channel catfish Ictalurus punctatus and American white pelican Pelecanus erythrorhynchos in the USA based on life-cycle and molecular data. Systematic Parasitology 52: 81-96.

Stickley, A. R., Jr. and K. J. Andrews. 1989. Survey of Mississippi catfish farmers on means, effort, and costs to repel fish-eating birds from ponds. Pages 105-108 in Proceedings Fourth Eastern Wildlife Damage Control Conference. Madison, Wisconsin, 25-28 September 1989 .

Strait, L. E. and N. F. Sloan. 1975. Movements and mortality of juvenile white pelicans from North Dakota. Wilson Bulletin 87: 54-59.

Terhune, J. S., D. J. Wise, and L. H. Khoo. 2003. Bolbophorus confusus infections in channel catfish in northwestern Mississippi and effects of water temperature on emergence of cercariae from infected snails. North American Journal of Aquaculture 64: 70-74.

U.S. Department of Agriculture. 2003. Catfish Production. National Agricultural Statistics Service, Washington, DC. (http://jan.mannlib.cornell.edu/reports/ nassr/other/pcf-bbc/2003/cfpd0203.pdf).

Venable, D. L., A. P. Gaude III and P. L. Klerks. 2000. Control of the trematode Bolbophorus confusus in channel catfish Ictalurus punctatus ponds using salinity manipulation and polyculture with black carp Mytopharyngodon piceus. Journal of the World Aquaculture Society 31: 158-166.

Wywialowski, A. P. 1999. Wildlife-caused losses for producers of channel catfish (Italurus punctatus) in 1996. Journal of the World Aquaculture Society 30: 461-472. 